ISSN 1979-5572 (print)

ISSN 2541-6480 (online

http://ejurnal.iainpare.ac.id/index.php/kuriositas

KURIOSITAS

Media Komunikasi Sosial dan Keagamaan

Volume 11

No. 1, Juni 2018

Halaman 1-18

\title{
OPTIMALISASI BAHAN AJAR PENDIDIKAN AGAMA ISLAM BERBASIS TEKNOLOGI INFORMASI DALAM MENINGKATKAN MINAT DAN HASIL BELAJAR SISWA
}

\author{
Abdul Waris \\ SMPN 1 Cempa \\ waris254@gmail.com
}

\begin{abstract}
This article discusses the relationship between the usage of IT-based teaching materials on Islamic education and learning interests with learning outcomes of Student in SMPN 1 Cempa Pinrang. This research was a field research. Refereeing from the type of data, this study included quantitative research. The approach used was the pedagogical approaches. Data were obtained through a questionnaire that had been tested for validity and reliability, then the data were analyzed using descriptive and inferential method. These results indicated that; perception of students on the use of IT-based teaching materials of PAI was in medium category, while PAI learning interest of students was in the high category. This study showed that the use of IT-based teaching materials of PAI and interests simultaneously can give a positive contribution to the learning outcomes of PAI. The implication of this research is that the use of IT-based teaching materials of PAI will provide a significant contribution in the implementation of the learning process for teachers because of the use of IT-based teaching materials of PAI provides convenience in learning so the
\end{abstract}


impact on the effectiveness of the learning process that can further enhance the learning outcomes of students.

Keywords: Teaching Materials, Study Interests, Study results.

\begin{abstract}
ABSTRAK
Artikel ini membahas tentang hubungan antara penggunaan bahan ajar Pendidikan Agama Islam berbasis IT dan minat dengan hasil belajar peserta didik SMPN 1 Cempa Kabupaten Pinrang. Penelitian ini merupakan penelitian lapangan (field research). Berdasarkan data yang digunakan, penelitian ini menggunakan pendekatan kuantitatif. Pendekatan yang digunakan adalah pendekatan pedagogis. Data diperoleh melalui kuesioner yang telah diuji validitas dan reliabilitasnya, kemudian data dianalisis secara deskriptif dan inferensial. Hasil penelitian ini menunjukkan bahwa; persepsi peserta didik terhadap penggunaan bahan ajar PAI berbasis IT dalam kategori sedang, sementara minat belajar PAI peserta didik dalam kategori tinggi. Penelitian ini menunjukkan bahwa penggunaan bahan ajar PAI berbasis IT dengan dukungan minat secara bersama-sama dapat memberikan konstribusi positif terhadap hasil belajar PAI. Implikasi dalam penelitian ini adalah bahwa Penggunaan bahan ajar PAI berbasis IT akan memberi sumbangan signifikan dalam pelaksanaan proses pembelajaran bagi guru karena penggunaan bahan ajar PAI berbasis IT ini memberikan kemudahan dalam pembelajaran sehingga berdampak pada efektifitas proses pembelajaran yang selanjutnya dapat meningkatkan hasil belajar peserta didik.
\end{abstract}

Kata Kunci: Bahan Ajar IT, Minat Belajar, Hasil Belajar PAI.

\title{
PENDAHULUAN
}

Pendidikan dipandang sebagai proses pembelajaran dalam mengoptimalkan sumber daya manusia berupa potensi, kecakapan dan karakteristik pribadi peserta didik. Potensi, kecakapan, dan karakter ini dianggap sebagai dasar dalam meningkatkan daya saing Sumber Daya Manusia (SDM) pada suatu bangsa. Hal ini menempatkan pendidikan 
sebagai salah satu tolak ukur dalam perkembangan suatu bangsa. Oleh karena itu pengembangan dunia pendidikan sanagt menentukan pengembangan SDM (Roqib 2009). Dasar hukum yang menjadi landasan pengembangan pendidikan yaitu Peraturan Pemerintah nomor 19 tahun 2005, yang mensyaratkan guru untuk mengembangkan materi pembelajaran, yang kemudian dipertegas melalui Peraturan Menteri Pendidikan Nasional (Permendiknas) nomor 41 tahun 2007 tentang Standar Proses untuk mencapai proses pembelajaran yang efisien dan efektif meliputi perencanaan, pelaksanaan, penilaian hasil dan pengawasan proses (BSNP 2007).

Pemanfaatan media pembelajaran secara tepat dalam mentransformasi materi pembelajaran yang dilakukan oleh seorang guru merupakan salah satu upaya untuk mencapai pendidikan yang bermutu. Upaya tersebut diperuntukkan bagi peserta didik yang belum dapat menerima pesan yang disampaikan guru, maka penggunaan media sangat dianjurkan. Penggunaan media juga dimanfaatkan untuk menghindari adanya miscommunication antara peserta didik dan guru. Dalam proses pembelajaran Pendidikan Agama Islam (PAI), pemanfaatan media oleh tenaga pengajar dalam hal ini guru memiliki arti cukup penting, dengan mempertimbangkan secara empiris bahwa hasil dari pembelajaran PAI selama ini masih kurang, yang disebabkan oleh perhatian guru sendiri yang masih kurang atas penggunaan komponen media pembelajaran.

Pembelajaran PAI berorientasi untuk pada pembelajaran peserta didik yang dapat menumbuhkan daya tarik, daya dorong dan minat belajar secara kontinu mempelajari ajaran Agama Islam baik yang berbasis pengamalan maupun yang berbasis pengetahuan (Muhaimin 2002). Sedangkan salah satu permasalahan mutu pendidikan di Indonesia adalah mutu proses pembelajaran yang berkaitan dengan metode, kurikulum, manajemen sekolah dan minat belajar peserta didik yang tergolong masih rendah. 
Kuriositas: Media Komunikasi Sosial dan Keagamaan

Vol. 11 No.1, Juni 2018: h.1-18

Perkembangan IT membawa pengaruh yang cukup signifikan terhadap perkembangan dunia pendidikan dan pembelajaran. Keanekaragaman penyajian bahan ajar yang digunakan oleh guru mengindikasikan perkembangan dunia pendidikan. Majid mengelompokkan bahan ajar ke dalam empat; (1). jenis bahan Ajar Cetak; (2). Bahan Ajar Dengar (Audio); (3). Bahan Ajar Pandang Dengar (Audio Visual); dan (4). Bahan Ajar Interaktif (Madjid 2007). Bahan ajar interaktif menurut Majid adalah multimedia interaktif yang merupakan kombinasi dari dua atau lebih media (audio, teks, grafik, gambar, animasi, dan video) yang oleh penggunanya dimanipulasi untuk mengendalikan perintah atau perilaku alami dari suatu presentasi (Madjid 2007).

Bahan ajar berbasis IT dimanfaatkan sebagai alat bantu guru dalam proses pembelajaran dan sebagai sistem pembelajaran individual sehingga peserta didik dapat langsung berinteraksi langsung dengan IT (Rusman 2009). Guru Pendidikan Agama Islam harus bisa menggunakan dan memanfaatkan bahan ajar PAI berbasis IT yang telah disediakan oleh pihak sekolah dari segi pengadaan, pemeliharaan dan pemanfaatan media untuk kelancaran proses belajar mengajar terutama dalam pembelajaran pendidikan Agama Islam.

Berdasarkan observasi awal yang dilakukan di lokasi penelitian, ditemukan bahwa penggunaan bahan ajar berbasis IT telah dilaksanakan dan dimanfaatkan oleh guru PAI di SMPN 1 Cempa Pinrang, akan tetapi belum diketahui secara empiris dampak penggunaan media ataupun bahan ajar berbasis IT terhadap mutu peserta didik dalam hal minat dan hasil belajar. Berdasarkan uraian masalah di atas, maka penulis tertarik untuk melakukan analisis mengenai hubungan penggunaan bahan ajar PAI berbasis IT dan minat terhadap Hasil Belajar Peserta didik SMPN 1 Cempa Kabupaten Pinrang.

\section{METODE}

Penelitian ini secara umum menggunakan pendekatan kuantitatif, dengan melakukan pengumpulan data yang objektif, valid karena 
berusaha mendapatkan data yang obyektif, valid, dan reliabel dengan menggunakan data yang berbentuk angka (Sugiyono 2002). Variabel yang diamati dalam penelitian ini terdiri atas variable bebas $X_{1}$ yang merepresentasikan Penggunaan Bahan Ajar PAI berbasis IT. Variabel bebas $X_{2}$ sebagai minat belajar dan variable terikat $Y$ sebagai Hasil belajar. Dengan mengacu pada hubungan penggunaan media belajar dan minat belajar terhadap hasil belajar maka penelitian ini juga fokus pada analisis regresi dan korelasi multivariate (Purwanto 2010).

Paradigma dalam penelitian ini adalah penggunaan bahan ajar berbasis IT sebagai media pembelajaran dalam meningkatkan minat dan hasil belajar dan pada prinsipnya adalah bagaimana guru membuat proses pembelajaran bisa berjalan dengan efektif dan efisien. Penelitian ini dilaksanakan pada bulan Mei sampai bulan Juni 2017. Lokasi yang menjadi tempat penelitian ini adalah di SMPN 1 Cempa Kabupaten Pinrang. Adapun yang menjadi populasi dalam penelitian ini adalah peserta didik kelas VIII SMPN 1 Cempa Kab. Pinrang dengan jumlah sebanyak 185 orang dengan jumlah rombongan belajar 7 ruang pada kelas VIII. Dalam penentuan jumlah sampel digunakan formula Slovin (Riduwan 2005). Dengan jumlah populasi yang sama, semakin kecil toleransi kesalahan, semakin besar jumlah sampel yang dibutuhkan. Berdasarkan populasi dengan jumlah populasi sebanyak 185 orang, maka untuk mendapatkan tingkat kepercayaan 95\% atau batas toleransi kesalahan 5\%, maka jumlah sampel dalam penelitian ini sebanyak 127 peserta didik. Dalam penelitian ini, random sampling dipilih sebagai metode dalam pengambilan sampel.

Selanjutnya pengumpulan data dilakukan dengan menjadikan angket sebagai instrument penelitian. Dari data yang diperoleh selanjutnya dilakukan pengujian tingkat kevalidan atau tingkat kesahihan melalui uji validitas instrument. Menurut Suharsimi, metode yang dapat digunakan dalam melakukan uji validitas adalah menggunakan rumus Product Moment. Dalam hal ini peneliti menggunakan aplikasi program SPSS versi 22 (Statistical Package for Social Sciences 22). Untuk mengukur validitas 
instrumen kuesioner dalam penelitian ini digunakan rumus korelasi pearson product moment. Kriteria yang digunakan dalam menentukan hasil pengujian adalah apabila dari hasil perhitungan yang dilakukan dengan menggunakan rumus korelasi product moment diperoleh nilai hasil korelasi masing-masing instrumen dengan skor totalnya. Apabila di setiap butir pertanyaan instrumen lebih tinggi atau sama dengan kriteria standarnya $(\mathrm{r}$ $>0,50$ ) atau jika dibandingkan dengan r-tabel, maka butir dikatakan valid jika nilai korelasi butir > r-tabel $(\mathrm{df}=\mathrm{n}-2)$ (Suharsimi 2006). Selanjutnya untuk tingkat kehandalan instrument diukur dengan melakukan uji reliabilitas yang mempu menunjukkan arti bahwa suatu instrumen cukup dapat dipercaya untuk digunakan sebagai alat pengumpul data karena instrumen tersebut sudah baik.

\section{PEMBAHASAN}

Hasil penelitian yang diperoleh dengan menggunakan instrumen kuesioner ditampilkan secara deskriptif untuk memperoleh gambaran data sampel. Data yang ditampilkan secara deskriptif meliputi data variabel penggunaan bahan ajar Pendidikan Agama Islam (PAI) berbasis IT ( $\left.\mathrm{X}_{1}\right)$, minat belajar peserta didik $\left(\mathrm{X}_{2}\right)$ dan hasil belajar peserta didik (Y). Data hasil belajar diambil dari data hasil ujian semester genap peserta didik SMP Negeri 1 Cempa. Nilai-nilai yang diperoleh setelah pengolahan dari data mentah dengan menggunakan teknik analisis deskriptif, yaitu rata-rata, median, modus dan simpangan baku diuraikan dalam hasil-hasil berikut:

\section{Penggunaan Bahan Ajar PAI Berbasis IT.}

Hasil penelitian menunjukkan bahwa skor variabel penggunaan bahan ajar PAI berbasis IT dari persepsi peserta didik berada antara 15 sampai dengan 30, harga rata-rata sebesar 22.57, median 22.68, modus 22, varians 12.802 dan standar deviasi 3.578.

Berdasarkan hasil pengambilan dan pengolahan data, dapat dijelaskan bahwa skor total variabel penggunaan bahan ajar PAI berbasis IT adalah 2867, skor teoritis tertinggi variabel ini tiap responden adalah 10 
x $3=30$, berdasarkan jumlah responden yang didapatkan yaitu 127 orang, maka diperoleh $30 \times 127=3810$ sebagai skor kriterium. Sehingga, penggunaan bahan ajar PAI berbasis IT adalah $2867: 3810=0.75$ atau 75 persen dari kriterium yang ditetapkan. Jadi dapat disimpulkan bahwa penggunaan bahan ajar PAI berbasis IT termasuk kategori "sedang" berdasarkan kriteria persentase yang telah ditetapkan pada tabel 3.2. Hal tersebut sesuai dengan hasil pengamatan di lapangan bahwa penggunaan bahan ajar PAI berbasis IT di SMPN 1 Cempa Kabupaten Pinrang dilakukan secara baik sehingga dapat meningkatkan hasil belajar peserta didik.

Selanjutnya ditampilkan pula hasil pengujian validitas dan realibilitas instrumen yang digunakan dalam memperoleh data penggunaan bahan ajar PAI berbasis IT di SMPN 1 Cempa, sebagaimana berikut ini:

\section{Uji Validitas}

Hasil uji validitas menunjukkan bahwa semua item instrumen sebanyak 10 item adalah valid dimana $R_{h i t u n g}>R_{\text {tabel. }}$

\section{Uji realibilitas}

Hasil perhitungan diperoleh nilai alpha ( $\mathrm{r}$ hitung) sebesar 0.845 lebih besar dari $\mathrm{r}$ tabel 0.174 dan berada pada nilai 0.81-1.00, pada kategori tinggi sekali. Dengan hasil ini, maka dapat dinyatakan item-item instrumen variabel $\mathrm{X}_{1}$ dinyatakan reliabel dan konsisten.

\section{Minat Belajar PAI Peserta Didik SMPN 1 Cempa}

Hasil penelitian menunjukkan bahwa skor variabel minat belajar PAI peserta didik SMPN 1 Cempa berada antara 27 sampai dengan 45, harga rata-rata sebesar 37.31 median 37.50, modus 37, varians 16.722 dan standar deviasi 4.089. Berdasarkan hasil pengambilan data, dapat dijelaskan bahwa skor total variabel minat belajar PAI peserta didik SMPN 
1 Cempa yang diperoleh dari hasil penelitian adalah 4738, skor teoritis tertinggi variabel ini tiap responden adalah $15 \times 3=45$, karena jumlah responden 127 orang, maka skor kriterium adalah $45 \times 127=5715$. Sehingga, minat belajar PAI peserta didik SMPN 1 Cempa adalah 4738 : $5715=0.83$ atau 83 persen dari kriterium yang ditetapkan. Jadi dapat disimpulkan bahwa minat belajar PAI peserta didik SMPN 1 Cempa termasuk kategori "tinggi", berdasarkan kriteria kategori yang telah ditetapkan pada tabel 3.2. Hal tersebut sesuai dengan hasil pengamatan di lapangan bahwa minat belajar PAI peserta didik SMPN 1 Cempa Kabupaten Pinrang menunjukkan peningkatan karena penggunaan bahan ajar PAI berbasis IT.

Selanjutnya ditampilkan pula hasil pengujian validitas dan realibilitas instrumen yang digunakan dalam memperoleh data minat belajar PAI peserta didik di SMPN 1 Cempa, sebagai berikut:

\section{Uji Validitas}

Perhitungan validitas instrumen menggunakan aplikasi program SPSS versi 22 diperoleh bahwa hasil uji validitas meunjukkan bahwa semua item instrumen sebanyak 15 item adalah valid dimana $T_{\text {hitung }}>\mathrm{T}_{\text {tabel. }}$.

\section{Uji realibilitas}

Uji reliabilitas dilakukan untuk menilai konsistensi sebuah instrumen. Dasar pengujian reliabilitas adalah jika nilai alpha ( $\mathrm{R}$ hitung) lebih besar dari nilai $\mathrm{R}$ tabel maka item-item instrumen dinyatakan reliabel dan konsisten, sebaliknya jika nilai alpha ( $R$ hitung) lebih kecil dari $R$ tabel maka item-item instrumen dinyatakan tidak reliabel atau tidak konsisten.

Analisis reliabilitas menggunakan pengujian reliabilitas internal dengan rumus Spearmen-Brown dan Guttman (Spilt-Half Method) yang perhitungannya dilakukan menggunakan software SPSS for windows. Adapun hasil uji realibilitas diperoleh nilai alpha ( $\mathrm{r}$ hitung) sebesar 0.745 lebih besar dari $r$ tabel 0.174 dan berada pada nilai, 0.61-0.80, pada kategori tinggi, berdasarkan kriteria realibilitas yang telah ditetapkan tabel 3.1. 
Hasil ini menunjukkan bahwa item-item instrumen variabel $\mathrm{X}_{2}$ dinyatakan reliabel dan konsisten.

\section{Hasil Belajar PAI peserta didik SMPN 1 Cempa Kabupaten Pinrang.}

Hasil penelitian menunjukkan bahwa skor variabel hasil belajar PAI peserta didik SMPN 1 Cempa Kabupaten Pinrang berada antara 78 sampai dengan 95 , harga rata-rata sebesar 87.26 , median 87.45 , modus 87 , varians 13.559 dan standar deviasi 3.682.

Berdasarkan hasil rangkuman statistic, diperoleh nilai rata-rata hasil belajar 127 peserta didik SMPN1 Cempa adalah 87.26. Nilai rata-rata hasil belajar mata pelajaran PAI ini dapat dikategorikan "baik" berdasarkan kriteria yang telah ditetapkan pada tabel 3.3. Sementara, jika nilai rata-rata hasil belajar peserta didik didasarkan pada Kriteria Ketuntasan Minimal (KKM) sekolah yaitu nilai 75, maka semua peserta didik (responden) dinyatakan tuntas dalam proses pembelajaran PAI.

\section{Pengujian Hipotesis}

\section{Uji Prasyarat}

Sebelum pengujian hipotesis, maka terlebih dahulu dilakukan uji prasyarat statistik agar proses analisis dan pengambilan keputusan tidak menyimpang dari kebenaran yang seharusnya.

\section{Uji Normalitas}

Uji normalitas dilakukan untuk mengetahui apakah data sampel yang diambil dari populasi berdistribusi normal atau tidak. Berdasarkan hasil pengujian normalitas data sebagaimana pada tabel di atas, diketahui bahwa variabel $X_{1}$ (penggunaan bahan ajar PAI berbasis IT) memperoleh nilai signifikansi $0.087>0.05$, variabel $\mathrm{X}_{2}$ (Minat Belajar) nilai signifikansinya adalah $0.066>0.05$, dan variabel Y (Hasil belajar) dengan nilai signifikansi $0.088>0.05$. Sehingga dapat dapat disimpulkan bahwa ketiga data yang diuji berdistribusi normal. 
Kuriositas: Media Komunikasi Sosial dan Keagamaan

Vol. 11 No.1, Juni 2018: h.1-18

\section{Uji Linieritas}

Uji linieritas dimaksudkan untuk mengetahui apakah hubungan masing-masing variabel bebas yang dijadikan prediktor mempunyai hubungan linear atau tidak tetap terhadap variabel terikat. Dasar pengujian linieritas adalah, apabila nilai signifikansi $<0.05$ maka terjadi hubungan linier antara variabel. Berdasarkan kedua hasil pengujian, dapat dijelaskan bahwa baik antara Variabel $X_{1}$ terhadap $Y$ maupun $X_{2}$ terhadap variabel $Y$ memiliki nilai signifikan linieritas yang sama yaitu nilai signifikansi $0.000<0.05$. Sehingga dapat disimpulkan bahwa hubungan antara variabel bersifat linier. Dengan demikian prasyarat linieritas dapat terpenuhi.

\section{Uji Hipotesis}

Dalam penelitian ini telah diajukan beberapa hipotesis, yang akan diuji dengan menggunakan statistik inferensial melalui teknik regresi ganda dan korelasi. Hipotesis 1 dan 2 menggunakan analisis regresi dan korelasi sederhana, sedangkan hipotesis 3 diuji dengan menggunakan analisis regresi ganda, yang kemudian dilanjutkan pula mencari sumbangan efektif secara bersama-sama variabel bebas terhadap variabel terikat. Pengujian tersebut secara rinci diuraikan sebagai berikut:

\section{Hubungan Antara Penggunaan Bahan Ajar PAI Berbasis IT dengan Hasil Belajar PAI Peserta Didik SMPN 1 Cempa Kabupaten Pinrang.}

Hipotesis pertama yang diajukan "ada hubungan positif antara penggunaan bahan ajar PAI berbasis IT terhadap hasil belajar PAI peserta didik SMPN 1 Cempa Kabupaten Pinrang". Dengan kata lain diduga semakin tinggi penggunaan bahan ajar PAI berbasis IT, semakin tinggi pula hasil belajar PAI peserta didik SMPN 1 Cempa Kabupaten Pinrang, sebaliknya semakin rendah penggunaan bahan ajar PAI berbasis IT, semakin rendah pula hasil belajar PAI peserta didik SMPN 1 Cempa Kabupaten Pinrang. 
Dasar pengujian hipotesis di atas adalah: Jika nilai signifikansi < 0.05 maka terdapat korelasi dengan kata lain, $\mathrm{H}_{0}$ ditolak dan $\mathrm{H}_{a}$ diterima. Sebalinkya, jika nilai signifikansi $>0.05$ maka tidak terdapat korelasi dengan kata lain $\mathrm{H}_{0}$ diterima dan $\mathrm{H}_{a}$ ditolak.

Koefisien korelasi parsial antara $X_{1}$ terhadap $Y$ dengan mengontrol $\mathrm{X}_{2}$ dapat dilihat pada tabel hasil analisis berikut ini:

Dari hasil analisis diperoleh $\mathrm{r}_{\mathrm{x} 1 \mathrm{y}}=0.356$ dan $p$-value $=0.000<0.05$ artinya $\mathrm{H}_{\mathrm{o}}$ ditolak atau $\mathrm{H}_{a}$ diterima. Dengan demikian korelasi antara penggunaan bahan ajar PAI berbasis IT $\left(\mathrm{X}_{1}\right)$ dengan hasil belajar PAI peserta didik SMPN 1 Cempa Kabupaten Pinrang (Y) dengan mengontrol variabel minat belajar PAI peserta didik $\left(\mathrm{X}_{2}\right)$ adalah signifikan. Dapat disimpulkan bahwa terdapat hubungan positif antara penggunaan bahan ajar PAI berbasis IT terhadap hasil belajar PAI peserta didik SMPN 1 Cempa Kabupaten Pinrang.

\section{Hubungan Antara Minat Belajar PAI terhadap Hasil Belajar PAI Peserta Didik SMPN 1 Cempa Kabupaten Pinrang.}

Hipotesis kedua yang diajukan "ada hubungan positif antara minat belajar PAI dengan hasil belajar PAI peserta didik SMPN 1 Cempa Kabupaten Pinrang". Dengan kata lain diduga semakin tinggi minat belajar PAI, semakin tinggi pula hasil belajar PAI peserta didik SMPN 1 Cempa Kabupaten Pinrang, sebaliknya semakin rendah minat belajar PAI, semakin rendah pula hasil belajar PAI peserta didik SMPN 1 Cempa Kabupaten Pinrang.

Secara statistik koefisien korelasi parsial antara $X_{2}$ terhadap $Y$ dengan mengontrol $X_{1}$. Untuk menguji hipotesis di atas maka dirumuskan dasar pengujian yaitu: Jika nilai signifikansi $<0.05$ maka terdapat korelasi, dengan kata lain $\mathrm{H}_{0}$ ditolak dan $\mathrm{H}_{a}$ diterima. Sebalinkya, jika nilai signifikansi > 0.05 maka tidak terdapat korelasi, dengan kata

Dari hasil analisis diperoleh $\mathrm{r}_{\mathrm{x} 2 \mathrm{y}}=0.870$ dan $p$-value $=0.000<0.05$ artinya $\mathrm{H}_{\mathrm{o}}$ ditolak atau $\mathrm{H}_{\mathrm{a}}$ diterima. Dengan demikian korelasi antara minat belajar PAI $\left(\mathrm{X}_{2}\right)$ terhadap hasil belajar PAI peserta didik SMPN 1 Cempa 
Kabupaten Pinrang ( $\mathrm{Y}$ ) dengan mengontrol variabel penggunaan bahan ajar berbasis IT $\left(\mathrm{X}_{1}\right)$ adalah signifikan. Dapat disimpulkan bahwa terdapat hubungan positif antara minat belajar PAI peserta didik terhadap hasil belajar PAI peserta didik SMPN 1 Cempa Kabupaten Pinrang.

\section{Hubungan Antara Penggunaan Bahan Ajar PAI Berbasis IT dan Minat Belajar Secara Bersama-Sama dengan Hasil Belajar PAI Peserta Didik SMPN 1 Cempa Kabupaten Pinrang.}

Hipotesis ketiga yang diajukan "ada hubungan positif antara penggunaan bahan ajar PAI berbasis IT dan minat belajar secara bersamasama terhadap hasil belajar PAI peserta didik SMPN 1 Cempa Kabupaten Pinrang". Dasar pengujian hipotesis di atas adalah: Jika nilai signifikansi < 0.05 maka terdapat korelasi, dengan kata lain $\mathrm{H}_{0}$ ditolak dan $\mathrm{H}_{a}$ diterima. Sebalinkya, jika nilai signifikansi > 0.05 maka tidak terdapat korelasi, dengan kata lain $\mathrm{H}_{0}$ diterima dan $\mathrm{H}_{a}$ ditolak. Berdasarkan hasil analisis regresi ganda antara penggunaan bahan ajar PAI berbasis IT $\left(\mathrm{X}_{1}\right)$ dan minat belajar PAI peserta didik $\left(\mathrm{X}_{2}\right)$ dengan hasil belajar PAI peserta didik $(\mathrm{Y})$, dapat diketahui bahwa nilai koefisien regresi $b_{1}=0.181\left(\mathrm{X}_{1}\right), \mathrm{b}_{2}=0.732\left(\mathrm{X}_{2}\right)$, dan nilai konstanta 55.856. Dengan demikian bentuk antara variabel penggunaan bahan ajar PAI berbasis IT $\left(\mathrm{X}_{1}\right)$ dan dukungan minat belajar PAI peserta didik $\left(\mathrm{X}_{2}\right)$ terhadap hasil belajar PAI peserta didik $(\mathrm{Y})$ dapat dinyatakan dalam persamaan arah regresi, yaitu:

$$
Y=55.856+0.181 X_{1}+0.732 X_{2}
$$

Untuk mengetahui apakah model persamaan regresi tersebut dapat digunakan untuk menarik kesimpulan atau apakah persamaan regresi yang telah diperoleh signifikan atau tidak, dapat diketahui dengan menggunakan analisis varians (uji-F). kriteria penilaian adalah Fhitung $>$ Ftabel. Koefisien korelasi ganda (secara bersama-sama) dapat dilihat pada tabel berikut: 
Pada tabel model summary, diperoleh koefisien korelasi ganda $\left(r_{y \times 1 \times 2}\right)=0.929$ atau dalam kategori hubungan "sangat kuat". Nilai lainnya yang penting dilihat adalah nilai F dimana Fhitung $>F_{\text {tabel, }}$ yaitu: $389.852>3.07$ serta nilai sig $F=0.000<0.05$. Hal ini berarti $\mathrm{H}_{\mathrm{o}}$ ditolak dan Ha diterima. Dengan demikian koefisien korelasi ganda antara $X_{1}$ dan $X_{2}$ terhadap $Y$ adalah berarti atau signifikan. Sedangkan koefisien determinasinya dari tabel model summary, diperoleh $R$ square $=0.863$ yang mengandung makna $86.3 \%$ variasi skor hasil belajar PAI peserta didik (Y) dapat dijelaskan oleh komponen penggunaan bahan PAI berbasis IT $\left(\mathrm{X}_{1}\right)$ dan dukungan minat belajar PAI $\left(\mathrm{X}_{2}\right)$ secara bersama-sama.

Berdasarkan hasil analisis of varians, maka didapatkan nilai signifikansi 0.000 dan nilai Fhitung 389.852. Hasil ini menunjukkan bahwa nilai signifikansi $0.000<0.05$ yang dapat disimpulkan bahwa kedua variabel independent $X_{1}$ (penggunaan bahan ajar PAI berbasis IT) dan $X_{2}$ (Minat Belajar) berpengaruh bersama-sama secara signifikan terhadap variabel dependent (Hasil Belajar).

Setelah dilakukan pengujian terhadap ketiga hipotesis ditemukan kesimpulan bahwa hipotesis nihil yang diuji ternyata ditolak dan hipotesis alternatif diterima. Hipotesis pertama yang diuji adalah hubungan antara persespsi penggunaan bahan ajar PAI berbasis IT terhadap hasil belajar. Dari hasil pengujian ditemukan bahwa Hasil penelitian menyimpulkan adanya hubungan positif antara penggunaan bahan ajar PAI berbasis IT terhadap hasil belajar PAI peserta didik SMPN 1 Cempa Kabupaten Pinrang. Dengan demikian, dapat disimpulkan bahwa penggunaan bahan ajar PAI berbasis IT memiliki hubungan positif dengan hasil belajar peserta didik.

Penggunaan bahan ajar PAI berbasis IT menunjang proses pembelajaran. Hal itu disebabkan karena bahan ajar PAI berbasis IT memberi nuansa pembelajaran yang menarik perhatian peserta didik. Selain itu, bahan ajar PAI berbasis IT berdampak pula pada kemudahan peserta didik dalam memahami materi pembelajaran. Bahan ajar PAI 
berbasis IT selain memuat teks, juga memadukan gambar dan video pembelajaran. Media ini sangat membantu guru dalam proses pembelajaran khususnya di dalam kelas. Materi yang disajikan dapat disesuaikan dengan kurikulum 2013 dan dapat dikelola dengan mudah oleh guru.

Hasil penelitian ini berkaitan pula dengan teori pembelajaran yang mendasarkan pada argumentasi pentingnya bahan ajar yang bersifat audiovisual. Menurut Dale, bahan ajar yang dapat memadukan potensi audio dan visual dalam satu proses akan memudahkan pemahaman peserta didik. Dengan demikian bahan ajar PAI berbasis IT yang dimanfaatkan dalam pembelajaran ini membantu guru dan peserta didik. Bagi guru, bahan ajar ini memudahkan dalam menyampaikan materi pembelajaran, sementara bagi peserta didik akan memudahkan dalam memahami pembelajaran.

Hipotesis kedua yang diuji adalah hubungan antara minat belajar dengan hasil belajar PAI di SMPN 1 Cempa Kab. Pinrang. Hasil penelitian ini menunjukkan bahwa minat belajar memiliki hubungan positif terhadap hasil belajar PAI di SMPN 1 Cempa Kab. Pinrang. Dalam artian, semakin tinggi minat belajar peserta didik maka akan semakin tinggi pula hasil belajarnya. Sebaliknya, jika minat belajar rendah, maka hasil belajar peserta didik pun akan rendah.

Minat belajar peserta didik berkaitan dengan aktivitas peserta didik dalam mengikuti proses pembelajaran. Seperti, antusiasme peserta didik dalam mengikuti proses pembelajaran di dalam kelas, mencatat materi pembelajaran, memperhatikan penjelasan guru, memperhatikan tayangan yang disajikan oleh guru selama proses pembelajaran, dan mereview materi pembelajaran. Minat belajar PAI peserta didik dipengaruhi salah satunya oleh faktor eksternal, dari luar diri peserta didik. Faktor eksternal yang berpengaruh terhadap minat diantaranya adalah penggunaan bahan ajar PAI berbasis IT. Bahan ajar yang disajikan oleh guru berupa tayangan 
presentasi yang memadukan teks, gambar, audio, dan video yang mencakup semua materi pembelajaran PAI.

Selanjutnya hasil pengujian hipotesis ketiga yang menguji tentang hubungan antara penggunaan bahan ajar PAI berbasis IT dan minat belajar PAI secara bersama-sama terhadap hasil belajar. Secara statistik dapat dikemukan bahwa hasil perhitungan analisis korelasi diperoleh nilai $\mathrm{F}$ hitung sebesar 389.852 dengan probabilitas 0.000 jauh lebih kecil dari 0.05, nilai ini dibandingkan dengan nilai $\mathrm{F}$ tabel $(0.05 ; 2 ; 125)=3.07$ menunjukkan $\mathrm{F}$ hitung lebih besar dari $\mathrm{F}$ tabel berarti $\mathrm{H}_{0}$ ditolak $\left(\mathrm{H}_{\mathrm{a}}\right.$ diterima), artinya rata-rata penggunaan bahan ajar PAI berbasis IT dan minat belajar PAI terhadap hasil belajar peserta didik adalah identik. Uji F \{Anova\} mempertegas bahwa karena nilai probabilitas kurang dari 0.05 maka model regresi yang diperoleh dapat diberlakukan secara umum di lokasi penelitian serta mewakili kondisi populasi yang sebenarnya.

Besarnya korelasi dari hasil belajar PAI peserta didik secara kumulatif adalah cukup kuat hal ini dipertegas oleh $\mathrm{R}$ Square yang didapatkan sebesar 0.863 artinya $86.3 \%$ penggunaan bahan ajar PAI berbasis IT dengan dukungan minat belajar PAI secara bersama-sama dapat memberikan kontribusi terhadap hasil belajar PAI peserta didik SMPN 1 Cempa Kabupaten Pinrang. Sisanya ditentukan oleh faktor luar yang juga memberikan kontribusi terhadap hasil belajar PAI peserta didik yang tidak diteliti dalam penelitian ini.

Penelitian ini berhasil menunjukkan bahwa masih sangat memungkinkan adanya peningkatan hasil belajar PAI peserta didik SMPN 1 Cempa Kabupaten Pinrang selain dengan pemanfaatan bahan ajar berbasis IT dalam proses pembelajaran. Penggunaan media pembelajaran yang ditinjau hanya dalam tujuh hal yaitu; dari segi kegiatan pra pembelajaran, kegiatan inti pembelajaran, pendekatan dan penggunaan media pembelajaran, pemanfaatan sumber-sumber pembelajaran, pembelajaran yang memacu keterlibatan peserta didik, penilaian dan hasil 
Kuriositas: Media Komunikasi Sosial dan Keagamaan

Vol. 11 No.1, Juni 2018: h.1-18

belajar dan penutup untuk melakukan refleksi yang memberikan hubungan yang positif.

Selain itu, ada beberapa keterbatasan penelitian ini diantaranya adalah tidak dilakukannya analisis antara hubungan variabel penggunaan bahan ajar PAI berbasis IT $\left(X_{1}\right)$ dengan minat belajar peserta didik $\left(X_{2}\right)$. Selanjutnya penelitian ini hanya terbatas pada sekolah tertentu dan tidak membandingkannya dengan sekolah lainnya yang juga telah menerapkan kurikulum 2013.

Adapun kendala-kendala yang dihadapi dalam proses penelitian ini diantaranya; berkaitan dengan keterbatasan waktu penelitian mengingat proses pembelajaran di SMPN 1 Cempa sangat padat. Selain itu, wilayah dan lokasi penelitian yang cukup jauh dari wilayah kota sehingga akses terhadap internet masih menjadi kendala peneliti untuk mendapatkan sumber-sumber informasi pendukung dalam penelitian.

\section{SIMPULAN}

Penelitian mengenai hubungan pengunaan bahan ajar PAI berbasis IT dan minat dengan hasil belajar peserta didik dapat disimpulkan bahwa minat belajar PAI peserta didik SMPN 1 Cempa Kabupaten Pinrang berada pada kategori tinggi. Tingginya minat belajar PAI peserta didik SMPN 1 Cempa diduga dipengaruhi oleh penggunaan bahan ajar PAI berbasis IT oleh beberapa guru PAI. Skor rata-rata hasil belajar PAI peserta didik SMPN 1 Cempa Kabupaten Pinrang berada pada kategori tinggi dan berada di atas kriteria ketuntasan minimal (KKM). Ini terkait dengan minat yang tinggi. Antara penggunaan bahan ajar PAI berbasis IT dengan hasil belajar PAI peserta didik SMPN 1 Cempa Kabupaten Pinrang memperlihatkan hubungan positif yang signifikan.

Dengan demikian, dapat diungkapkan bahwa penggunaan bahan ajar PAI berbasis IT di SMPN 1 Cempa dapat meningkatkan hasil belajar PAI peserta didik. Hal ini dapat dilihat dari adanya hubungan positif yang signifikan minat belajar PAI dengan hasil belajar PAI peserta didik SMPN 1 
Cempa Kabupaten Pinrang. Sehingga dapat diungkapkan pula timbulnya minat belajar PAI dapat mengoptimalkan hasil belajar PAI peserta didik SMPN 1 Cempa Kabupaten Pinrang.

Penggunaan bahan ajar berbasis IT dan minat belajar PAI secara bersama-sama menunjukkan hubungan positif yang signifikan dengan hasil belajar PAI peserta didik di SMPN 1 Cempa. Hal ini dapat disimpulkan bahwa perpaduan dua variabel yakni penggunaan bahan ajar berbasis IT dan minat belajar PAI secara komprehensif dapat menjadi faktor yang dapat dioptimalkan untuk memperoleh hasil belajar PAI yang lebih.

\section{REFERENCE}

(1) Arikunto, Suharsimi. 1992. Prosedur Penelitian: Suatu Pendekatan Praktik. Rineka Cipta.

(2) BSNP. 2007. Permendiknas No. 41 2007:Standar Proses Pendidikan Dasar Dan Menengah.

(3) Efendy, R. (2015). HEGEMONI EPISTEMOLOGI RASIONAL BARAT DALAM KONSTRUKSI KURIKULUM PAI DI INDONESIA. AL-ISHLAH : Jurnal Studi Pendidikan, 13(2)

(4) Madjid, Abdul. 2007. Perencanaan Pembelajaran. Bandung: Remaja Rosda Karya.

(5) Muhaimin. 2012. Paradigma Pendidikaan Islam. Surabaya: Remaja Rosda Karya.

(6) Purwanto, M Pd. 2010. “Metodologi Penelitian Kuantitatif Untuk Psikologi Dan Pendidikan." Yogyakarta: Pustaka Pelajar.

(7) Riduwan, M B A. 2015. "Belajar Mudah Penelitian." Bandung, Perpustakaan Nasional RI: Katalog Dalam Penerbitan (KDT).

(8) Roqib, Muh. 2009. Ilmu Pendidikan Islam; Pengembangan Pendidikan Integratif Di Sekolah, Keluarga Dan Masyarakat. Lkis Pelangi Aksara.

(9) Rusman. 2009. Model-Model Pembelajaran: Mengembangkan Profesionalisme Guru. Rajawali Pers/PT Raja Grafindo Persada. 
Kuriositas: Media Komunikasi Sosial dan Keagamaan

Vol. 11 No.1, Juni 2018: h.1-18

(10) Saepudin, S. (2015). KINERJA GURU BAHASA ARAB DALAM PENGEMBANGAN BAHAN AJAR PADA MADRASAH ALIYAH DI PAREPARE. AL-ISHLAH : Jurnal Studi Pendidikan, 13(2)

(11) Sugiyono. 2002. Statistik Untuk Penelitian. Bandung: Alphabela.

(12) Suharsimi, Arikunto. 2006. "Prosedur Penelitian Suatu Pendekatan Praktik." Jakarta: Rineka Cipta.

(13) Sultan, S. (2015). PERILAKU HIPERAKTIF SISWA DI SMP NEGERI 2 PINRANG. AL-ISHLAH : Jurnal Studi Pendidikan, 13(2) 